\title{
Shanghai Style Antique Painting Exploration
}

\author{
Peng Peng \\ College of Architecture and Urban-Rural Planning \\ Sichuan Agricultural University \\ Chengdu, China
}

\begin{abstract}
This article takes antique painting, a special theme in shanghai style, as the example, and explores the historical background and cultural meaning of this vase flower theme which looks a lot like western still life painting. It points out that the painting form of antique painting has a close relationship with the omen custom in ancient China. It is the epitome of painting secularization under the background of commercialization, and the combination of omen custom and scholar epigraphy.
\end{abstract}

Keywords-Antique Painting; Shanghai Style; Omen Custom; Epigraphy

"Bogu" used to means knowing about the antique things. "Antique painting" means the painting of antique equipment, which originally came from the graphic illustration of unearthed artifacts. It was first seen in the book called Xuan-he antique painting by Wangfu, which is ordered by the Emperor Huizong of Song Dynasty. This book recorded the bronze ware collected by Song royals in Xuan-he temple from Shang dynasty to Tang dynasty. Therefore, all the paintings about antique equipment or copies of them, are called antique paintings by the later generations. For example: antique painting, antique vase, antique screen, etc. During the late Qing dynasty, there were some paintings with the theme of antique objects, flowers and plants in shanghai. The famous shanghai style painter named Zhao Zhiqian, Ren Bonian and Wuchangruo are all famous for the antique paintings. Among all the antique paintings, it is the ones that combining bronze ware rubbing and paintings which can mostly represent the characteristics of antique painting. They are bronze ware with flowers, branches and fruits, etc. This paper will take antique painting as an example to study the historical background and cultural meanings of this vase flower which is similar with western still life painting.

There might be a very close relation between antique painting and omen custom. Chenwu wrote in his book three decades' knowledge in Shanghai. A painter can always paint the four seasons with words at their hands. It might be a tiny skill, but can be regarded as an interesting thing in art circle. This kind of painting can be called year map when it is hanged out in the New Year. Plum, narcissus and bamboo are called year omen custom. Suichao, which is called spring festival now, is the first day in January by lunar calendar. The Book of History had said that it is the first day of a new year, of spring and of the first month. This is why it is called three beginnings. The first day of a year is also the New Year's Day of the Chinese lunar calendar". Omen is short for elegant offerings, which refers to the furnishings put on the desk to enjoy the sight including miniature garden, flower arrangement, seasonal fruits, rare rocks, artwork, antique and exquisite stationery, etc. In the old customs, in the Chinese New Year, people put an antique vase, basin, seasonal flowers or plants with mascot for good luck, which is called age omen. Since Song dynasty, this kind of ancient cooking vessel, wine sets and vase flowers are not only refined scholar's favorite furniture but also the popular theme in paintings of omen subject. In Taipei Palace Museum, there is a painting called Age omen painting by Dongxiang from Song dynasty. Bottle offerings of pine tree, plum and camellia are all in the painting. Gallipot flowers painting by Yao Yuehua painted the chrysanthemum. In Ming dynasty, the symbolic meaning of flowers is more obvious. There was a painting by Bian Wenjin. He put plums, pine trees, cypress, camellia, orchid, narcissus, lucid ganoderma, common nandina, red persimmon and Ruyi into the copper pot. All these ten kinds of materials have their own meanings. Xuande emperor Zhu Shanji painted a palm civet looking up at the white peony copper pot. Palm civet means long life and white peony means wealth and rank. Chenkuo painted the Safe Lotus Painting with the theme of vase lotus. The plain background of this painting set off the freshness of lotus. Till Qing dynasty, these lucky paintings were still very popular among both nobles and common people. According to the Kiyomiya Imperial Household Department Records, at the end of lunar year, court painter need to submit the spring festival paintings for palace decoration. Royalties and ministers who are good at painting will also give paintings to the emperor to wish happy new year. Even the emperor himself would paint age omen paintings. There used to exhibit ten pieces of paintings by Qianlong in Imperiel Palace of Beijing. Many painters in Yangzhou schools and shanghai schools were following the trend and had painted a lot of omen paintings. Wu Changshuo, who was regarded as the best in shanghai schools would paint the age omen offerings every year to welcome the new year and to give it to friends. There were the Age Omen, plum blossom, omen scenery, valuable immortals, safeness and happiness, etc. Zhao Zhiqian, the pioneer of shanghai style, created paintings such as peace all year round, plum blossom, cold season, valuable spring, age omen offerings, etc. Xu Gujin, the outstanding representative of shanghai art circle, still have the two paintings called age omen and age omen offerings painted for Jianzhong Monk and Daocheng Monk in Suzhou. Ren Bonian also painted Lucky gold omen, 
green light and yellow volume, omen on the desk, immortals with children, book shelf omen, etc. There are many themes like great richness and longevity, safeness and fortune, prolong life, richness with children. And they all expressed the original meaning of omen paintings. No disturb from any vulgarian except for poetic prose. The scholars have both agreements and disagreements towards folk customs. And they have different aesthetic requirements towards flowers arrangement omen. Yuan Hong from Ming dynasty wrote: the indoor flower organ should be stunted in size, and copper vessels can only be chosen when they are small in size. Or else there would be no difference from the burning incense of common people. Although they are old, still vulgar. The vase for keeping flowers should also be fine and excellent. The most common ones are used vessels from families in south China. They are verdant and full of spots, and can be regarded as the golden house for flowers. In the second place, chinaware such as guanware, ge kiln, image kiln, and ding kiln are all the great lodge for flowers. Yuan Hongdao thinks that bronze ware is the first choice for vase, and the second choice is the five chinaware from Song dynasty. The taste of picking a vase is representative, as Zhen Heng also said that copper and tile are much more valuable than gold and silver when choosing the vase. Ancient people think that old copper can have the rustic smell when buried under the earth for years, which is good for keeping flowers. However, I think it is still the trend of pursuing for ancient objects that really matters. Since Song dynasty, the study of golden ancient implements has become a special learning. There were a series of work studying metal stones and ancient implements. Till Qing dynasty, under the support of government, loving ancient objects had become a national movement and people from all levels were all proud of that. As the records said, at the beginning of Kuang-hsu, scholars in Beijing all loved literary, history, paintings, ancient stones and bronze metals. The prices of all those ancient stuffs are rising, and most of the scholar officials were learning how to appreciate. Twenty years ago, scholars in Beijing appreciate each other through metal and stone. Things were the same outside Beijing, such as Miu xiaoshan from Jiangyin, Huang Zhongyou from Ruian, Shen Zipei from Jiaxing, Liang Hangshu from Fanyu, were all studying metal and stone. Its popularity were also reflected on the book writing. Learned from emperor huizong of song dynasty, Qianlong ordered scores of people to organize the Four Books, which were called Four Appreciations of Qianlong. There were also a lot of private family works about metal and stones such as two wine-vessels by Wuyun, golden stone index by Feng Yunpeng, etc. In a word, as the developing of metal and stone studying, scholars from late Qing dynasty were more and more interested in it. Many precious bronze and chinaware were becoming the first choice for omen. Their paintings and articles were also showing the characteristics of metal and stone trend. Kang Youwei wrote in his book that after Qianlong period, all the scholars would take metal and stones as their reasons of changing the history. During Xianfeng tongzhi period, stele study was popular among small children. All of who were speaking and writing Wei tablet. Shanghai are filled with scholars, and it is a city with the sense of literature. Painting and paintings about metals are very popular there. This popularity mobilized the revolution of painting, and has become the art trend. The painting of Shanghai scholar is secularization, but many of the scholars have the spirit of making friends with ancient people. They are all very obsessed with the metal stone paintings. Zhao Zhiqian and Wu Changshuo are the typical characteristics of shanghai schools. Zhao Zhiqian add metal and stones into his paintings, and transferred his experience achieved from calligraphy and seal cutting in his paintings, which makes the painting more tall and straight with the sense of ancient power. He built up a new character for shanghai school. Ren Xiongping and Zhao Zhiqian painted flowers and birds. With the official script style of writing, they added vigorous and simple interests into the painting, which is the real masterpiece. Zhao Zhiqian not only can make his painting looks like a book, but also chase after flexible writing style. He wrote for his painting ink pine that painting pine with ancient style of calligraphy is meant to chasing after the ancient meaning of the painting, and to study the painting style of Song and Yuan dynasty. Pan Tianshou estimates Zhao Zhiqian in China Painting History "he paints flowers and birds, the painting style is grand and antique. He is the pioneer of shanghai style and all the scholars admire him. Since then, there were few attentions payed to Nanshan School." Wu Changshuo loved tablet and bronze ware for his whole life. According to the record, April of guangxu eight years, he wrote morality lies in tile and brick to Jin Fujiang. Jin knows that $\mathrm{Wu}$ loves Fou, so he gave hime the precious Fou as a reward. Wu loved it so much that he called himself the father of Fou, and called his painting room Fou hut. The preface and postscript of his book is written as this"at the end of Yimao year, i saw the piece of Liuzhou's ancient vessel which is plain and dignified. I liked it so much that I painted a flower for him. " this directly showed his love toward ancient objects. Wu had studied ancient seal and seal character for a long time, and he consciously brought this epigraphy into his painting works. His paintings are all roust and forceful, shrewd but never lack of delicately beautiful. Other shanghai school painters such as Chen Laolian, Ren Xiongjing and Chen Bonian all gradually changed their painting style into more comfortable style after joining into shanghai school. And they are paying more attention to metal and stone sentiment. Although they are not famous for the calligraphy and seal cutting, they deeply understand the relations between paintings and calligraphy. Zheng Yimei once wrote: $\mathrm{Wu}$ Changshuo started to learn painting from Ren Bonian when he was fifty. Ren painted the plum and bamboo for him with only a few strokes. Wu took the painting home and studied it everyday. After a few sketches, he took them to Ren to modify and evaluate. Ren told him that he only painted the appearance of the bamboo and the plum is kind of swollen. Ren told him to make full use of what he is good at, and to paint flowers with seal characters, and apply the calligraphy skills into painting. $\mathrm{Wu}$ became more hardworking and communicate with Ren everyday. Ren also once said that he paints with calligraphy skills sometimes. Ren Xiong imitates the good painting works of ancient people all the 
time. He would change the canvas as long as there is any difference from original work. He never stops even during the midnight and finally his paintings became great.

Just because of the ancient object admiring and the goldstone emotions of shanghai school, the appearance of antique paintings is never more natural. During the creation of omen painting, shanghai school painters directly introduce ancient vessel pictures. The practical omen painting suddenly became the antique painting with cultural atmosphere. The popularity of antique painting in Qing dynasty also has some relations with its marketize background. As the developing of shanghai trade, a lot of painters were attracted to settle down in shanghai to sell their paintings for living. In order to make the folk people accept their paintings, they worked hard to learn folk art. And they tried to get close to citizen's taste. The metal and golden implements can express their emotions of appreciating ancient arts as well as safeness and happiness. For example, ancient vase and big orange symbols safety. Peony in the nine ting means richness and prosperity. Lily, persimmon and Ruyi represent everything goes as one's wishes. The four gentlemen, pine and cypress symbols the respectable personality. In common people's eyes, plum can be one of the combination elements of Xishangmeishao, which means happiness. Bamboo has the meaning of safeness. Pine and cypress are the symbol of longevity. The luxury ancient implements, combined with all kinds of flowers, pushed the great wishes such as age omen, richness and longevity, good luck into a natural atmosphere. Just as Luxun said "watching folk customs needs either calligraphy or paintings". Antique painting reflected the citizen's hobbies with the development of city economy, the pursuing on comfortable life and arts. Antique painting suit both refined and popular tastes, and t it is warmly welcomed. Otherwise, the all form technology of bronze vessels occurred in Qing dynasty directly promoted the birth of antique painting. The common chasing toward gold and metal promote the cooperation of collector, rubbing master and the painter to finish one work. Many shanghai school painters have applied this method. For example, Zhao Zhiqian, $\mathrm{Xu} \mathrm{Gu}$, Chen Shiceng, Ren Bonian, $\mathrm{Wu}$ Changshuo, etc. The complimentary close will be the Fou collected by Li Jiafu and $\mathrm{Wu}$ Changshuo. The painting of peony in Year Jichou, Hanshi Festival. The Zhou Duodun wrote "a friend give me the zhou duodun all form ink billiton as a present. I painted chrysanthemum, narcissus and painted antique age".

In a word, antique painting is the special topic for shanghai school, and it is the combination of age omen in Qing dynasty and scholar's interests in gold stone. The popularity has a very close relationship with that. Secondly, it caters to the market's need. We can say that antique painting is the production of this era. On one hand, it is the miniature of scholar secularization under the commercialization background which reflects the citizen's taste with the development of economy. On the other hand, a special aesthetic significance is achieved through its epigraphy. Age omen suits both refined and popular tastes.

\section{REFERENCES}

[1] Chen Wuwo, "Thirty Years' Records on Old Shanghai".Shanghai: Dadong Bookstore. 1928.04.

[2] Zhang Qiande, Yuan Hongdao, "Vase Flower History”.Beijing: China Bookstore.2012.07

[3] Wen Zhenheng, "Object Records”.Beijing: Jincheng Press.2010.08

[4] Luo zhenyu, "Complete Works of Luo Xuetang".Taipei: Cultural Press.1968.

[5] Jaing yihua,Wu genliang, "Complete Works of Kang Youwei”.Shanghai: Ancient Book Press.1987.

[6] Zhenjun, "Accident Hearings from Tianchi”.Taipei:Guangwen Bookstore. 1970.

[7] Ye Changzhi, "Stone Cconversation".Shenyang: Liaoning Education Press. 1988.

[8] Bai Qianshen, “Fushan's World: Evolution of Chinese Calligraphy in 17th Century".Beijing: Sanlian Bookstore. 2006

[9] Sunjie, "Ancient Shanghai Art".Shanghai: Shanghai University Press.2002.09

[10] Guangyi, “Comments on Wu Changshuo's Paintings and Poetry".Hang Zhou: Zhejiang People's Press.2003.

[11] Li Wancai, "Shanghai Painting Style".Chang Chun: Jilin Art Press.2003.

[12] Wang Zhongxiu, Mao Ziliang, Chenhui, "Examples of Metal and Stone Painters in Modern Times".Shanghai Pictorial Press. 2004.

[13] Xu Ke, "Stories in Qing Dynasty".Beijing: Commercial Press. 